\title{
Primary Uterine Hydatid Cyst: A Case Report
}

\author{
Primer Uterin Hidatik Kist: Olgu Sunumu
} \author{
Yusuf Yıldırım² \\ 'Department of General Surgery, Faculty of Medicine, Erzincan University, Erzincan, Turkey \\ 2Department of Gynecology and Obstetrics, Faculty of Medicine, Erzincan University, Erzincan, Turkey \\ ${ }^{3}$ Department of Patology, Faculty of Medicine, Erzincan University, Erzincan, Turkey \\ ${ }^{4}$ Department of Infectious Diseases, Faculty of Medicine, Erzincan University, Erzincan, Turkey
}

Kemal Peker ${ }^{1}$, Paşa Uluğ², Ümit Aslan Naykı², Cenk Naykı², ilyas Sayar, Faruk Karakeçili

\begin{abstract}
Echinococcosis, which is caused by echinococcus granulosus, is also known as cystic hydatid disease, unilocular echinococcosis or cystic echinococcosis. Cystic echinococcosis is an alarming public health problem in some countries. Although the liver and lung are the organs involved most commonly by the disease, it may appear rarely in other tissues as a primary disease. Here, we present a 66-year-old patient who is invoved in farm work work. A Uterine multiseptate hydatid cyst was found on radiological investigations and the patient underwent surgery. A total hysterectomy was carried out. There were no postoperative complications. (Turkiye Parazitol Derg 2013; 37: 302-4)
\end{abstract}

Key Words: Uterine hydatid cyst, E. granulosus, echinococcosis

Received: 09.08.2013

Accepted: 21.08 .2013

\section{ÖZET}

Ekinokokkozis; ekinokokus granulosus'un neden olduğu; kist hidatik hastalığı, uniloküler ekinokokkozis veya kistik ekinokokkozis olarak bilinir. Kistik ekinokokkozis bazı ülkeler için önemli bir problemdir. Karaciğer ve akciğer ensık lokalizasyonu olmakla birlikte nadir olarak diğer organlarda da görülebilmektedir. Çalışmamızda 66 yaşında çiftçilik yapan ve radyolojik olarak intrauterin yerleşimli multipil septalı bir kist hidatik vakası sunduk. Hasta opere edilerek total histerektomi yapıldı. Postoperatif dönemde herhangi bir komplikasyon gelişmedi. (Turkiye Parazitol Derg 2013; 37: 302-4)

Anahtar Sözcükler: Uterin hidatik kist, E. granulosus, ekinokokkozis

Geliş Tarihi: 09.08.2013

Kabul Tarihi: 21.08.2013

\section{INTRODUCTION}

Echinococcus granulosus tapeworms cause a zoonotic disease called Cystic echinococcosis. The definitive hosts which involve dogs, other canines hyenas and cats, carry the adult tapeworms subclinically. Since dogs have close relationships with human-beings, they are especially significant in zoonotic transmission. Intermediate hosts are at first asymptomatic, but the growth of larvae, which constitute cysts in crucial organs such as the liver and lungs, can cause illness and death. Cystic echinococcosis is an alarming public health problem in some countries and it could be an emerging or re-emerging disease in some regions. Almost 2-3 million human cases are estimated to occur worldwide (1). The most widespread form of the disease in humans and domesticated animals, cystic echinococcosis is brought about by $E$ granulosus. When the larvae of this organism develop as discrete single cysts, this is the least severe and

Address for Correspondence / Yazışma Adresi: Dr. Kemal Peker, Department of General Surgery, Faculty of Medicine, Erzincan University, Erzincan, Turkey. Phone: +90 4462122213 E-mail: k.peker@yahoo.com.tr doi:10.5152/tpd.2013.3216 


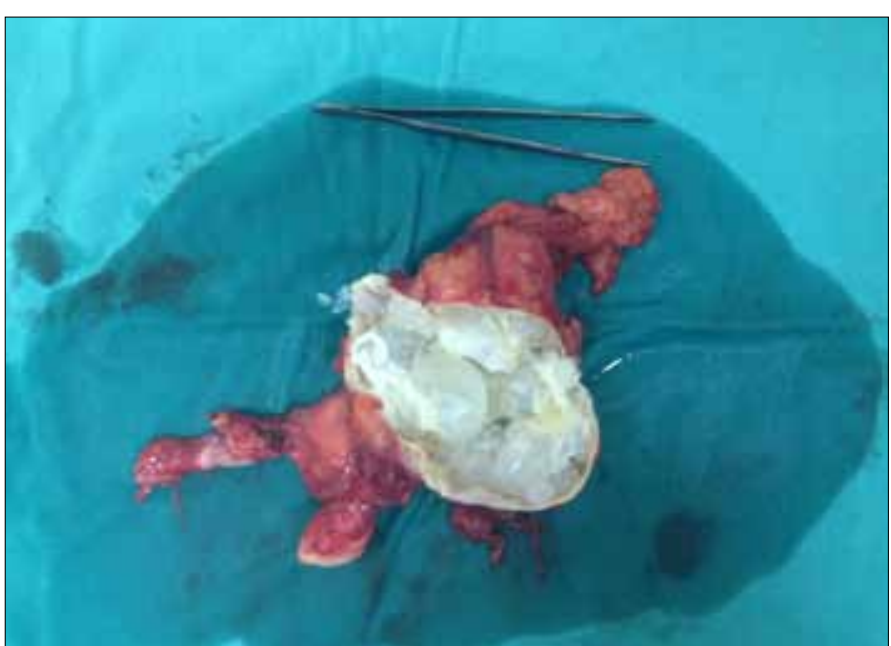

Figure 1. Geminatif membrane and daughter cysts observed macroscopic cross-section

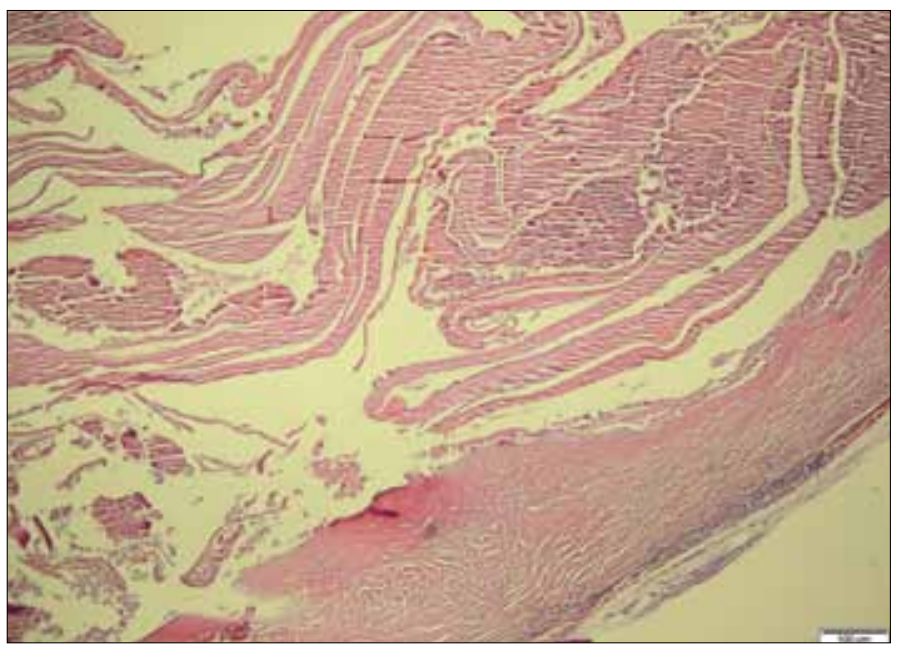

Figure 2. Histopathological findings (H\&E40X)

most curable form. Nonetheless, large or multiple cysts could cause irreversible damage to organs, and the rupture or puncture of the cyst can seed multiple organs with larvae or bring about anaphylactic reactions. Human beings characteristically become symptomatic many years after infection (2).

\section{CASE REPORT}

A 66 year-old female patient who had tenesmus and lower abdominal pain of three months duration visited the outpatient clinic. Physical examination showed abdominal tenderness. No significant suggestive diagnostic finding existed in the abdominal Xray. Ultrasonography (USG) of the abdomen showed a 10x7 $\mathrm{cm}$ sized cystic lesion of the uterus. A multiseptate cystic lesion of the uterus was revealed by Computed tomography (CT) scan. No specific findings were found in the patient's history. When the patient was admitted to the hospital, her blood pressure was $130 / 80 \mathrm{mmHg}$, body temperature was $36.8^{\circ} \mathrm{C}$, and the pulse was 78 per minute. Mild tenderness was determined in the abdominal area. Laboratory results revealed that all routine blood tests and tumor markers rank were within the normal range. Anti-echinococcus antibodies (IHA) screening was neg-

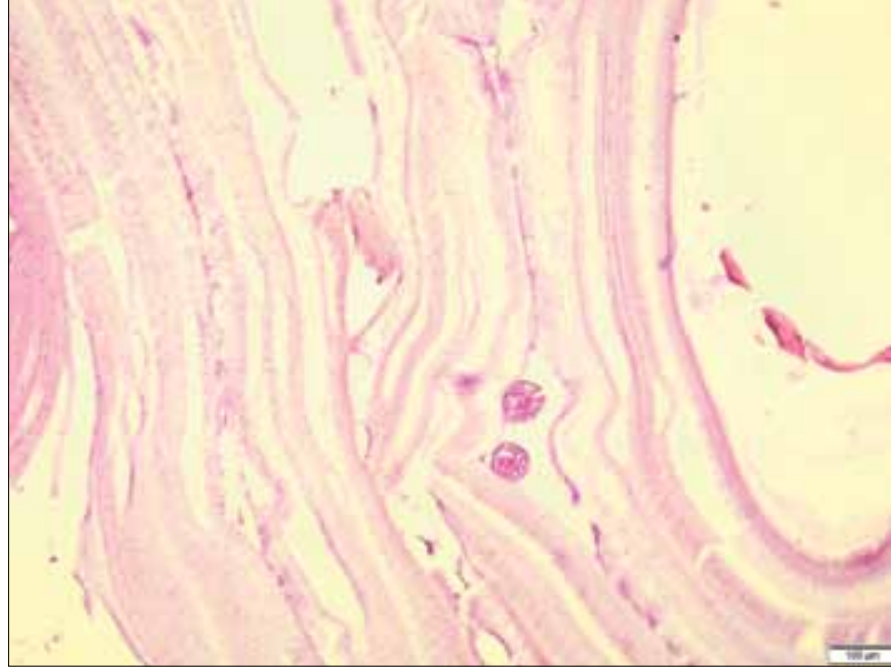

Figure 3. Histopathological findings (H\&E100X)

ative. The patient was operated on by the General and Gynecology Surgery Departments. The whole specimen was sent for pathological assessment (Figure 1).

Histopathological finding of $\mathrm{H}$ and $\mathrm{E}$ (Hematoxylin and Eosin) section revealed a double layered membrane with an outer laminated hyaline membrane and inner granular germinal layer (Figure 2, 3).

\section{DISCUSSION}

In addition to being an occupational disease with worldwide distribution, Cystic echinococcosis or Hydatid disease is one of the most significant zoonotic diseases $(3,4)$. A parasitic disease, cystic echinococcosis develops cysts which develop from Echinococus type cestodes both in humans and animals, and it continues to be an important health problem in our country (5).

The disease is more often encountered in areas where animal breeding conditions are poor and stray dogs exist. Human beings are infected with the parasite egg by contact with dogs or from contaminated food. The larvae of this parasite egg appear in the small intestine and penetrate the intestinal wall and thus enter the circulatory system (6). The common sites of hydatid disease are the liver (6570\%), lung (1025\%), peritoneum (818\%), spleen (23\%), kidney (14\%), subcutaneous $(12 \%)$, retroperitoneal $(0.51 \%)$, pancreas $(0.50 .8 \%)$, uterus and adnexa $(0.51 \%)$ and others sites $(0.13 \%(7)$. E. granulosus causes a slowly progressive unilocular, capsulated, noninvasive, chronic cystic lesion with a growth rate of $0.53 \mathrm{~cm} /$ year in their diameter which is non fatal and can be removed by surgical intervention (8). According to the treatment stage and localization, medical, surgical treatment and Puncture Aspiration Introduction of proscolocidal agent Reaspiration (PAIR) are utilized (9). Prior studies reported that the most common localisation for cyctic echinococcosisis is the liver, and the second common localisation is the lung (5). Rare intramuscular, gluteal. cervical and ovarian echinococcal diseases have also been reported (6-9) and here we present an intrauterine hydatid disease. 


\section{CONCLUSION}

Cystic echinococcosis still continues to be a very important health problem for poor countries. Cystic echinococcosis in the genital tract is rare and occurrence in the uterus is an extreme rarity. Differentiation between Cystic echinococcosis and malignant disease of the related organ is difficult. A careful examination of pelvic masses should be performed in endemic areas for detection of Cystic echinococcosis in order to avoid misdiagnosis.

Conflict of Interest: No conflict of interest was declared by the authors.

Financial Disclosure: The authors declared that this study has received no financial support.

Peer-review: Externally peer-reviewed.

Informed Consent: Written informed consent was obtained from patients who participated in this case.

Author Contributions: Concept - K.P.; Design - K.P., P.U.; Supervision - K.P., P.U.; Funding - K.P., P.U., Ü.A.N., C.N.; Materials - K.P., P.U., Ü.A.N., C.N., F.K., Y.Y.; Data Collection and/ or Processing - K.P., I.S.; Analysis and/or Interpretation - K.P., I.S.; Literature Review - K.P.; Writing - K.P.; Critical Review - K.P., P.U., Ü.A.N., CN., I.S., F.K., Y.Y.; Other - K.P.

Çıkar Çatışması: Yazarlar çıkar çatışması bildirmemişlerdir.

Finansal Destek: Yazarlar bu çalışma için finansal destek almadıklarını beyan etmişlerdir.

Hakem değerlendirmesi: Dış bağımsız.

Hasta Onamı: Yazılı hasta onamı bu olguya katılan hastalardan alınmıştır.
Yazar Katkıları: Fikir - K.P.; Tasarım - K.P., P.U.; Denetleme - K.P. P.U.; Kaynaklar - K.P., P.U., Ü.A.N., C.N.; Malzemeler - K.P., P.U., Ü.A.N., C.N., F.K., Y.Y.; Veri toplanması ve/veya işlemesi - K.P., I.S.; Analiz ve/veya yorum - K.P., I.S.; Literatür taraması - K.P.; Yazıyı yazan - K.P.; Eleştirel İnceleme - K.P., P.U., Ü.A.N., CN., I.S., F.K., Y.Y.; Diğer - K.P.

\section{REFERENCES}

1. Ito A, Urbani C, Jiamin $Q$, Vuitton DA, Dongchuan $Q$, Health DD, Craig PS, Zheng F, Schantz PM, Control of echinococcosis and cysticercosis: a public health challenge to international cooperation in China. Acta Trop 2003; 86: 3-17. [CrossRef]

2. McManus DP, Zhang W, Li J, Bartley PB, Echinococcosis. Lancet 2003; 362: 1295-304. [CrossRef]

3. Ray R, De PK, Karak K. Combine role of casoni test and indirect haemagglutination test in the diagnosis of hydatid disease. Indian $\mathrm{J}$ Med Microbiol 2002; 20: 79-82.

4. Rokni MB, Aminian B. Evaluation of the enzyme-linked immuno-electroTransfer blot (EITB) technique using hydatid Cyst antigens $\mathrm{B} / 5$ and total IgG antibodies In laboratory diagnosis of human hydatidosis. Pak J Med Sci 2006; 22: 127-31.

5. Ozekinci S, Bakir S, Mizrak B. Evaluation of Cystic Echinococcosis Cases Given a Histopathologic Diagnosis from 2002 to 2007 in Diyarbakir. Turkiye Parazitol Derg 2009; 33: 232-35.

6. Acar A, Rodop O, Yenilmez E, Baylan O, Oncul O. Case report: primary localization of a hydatid cyst in the adductor brevis muscle. Turkiye Parazitol Derg 2009; 33: 174-6.

7. Mushtaque M, Mir MF, Lone MA, Batt SH. Solitary subcutaneous gluteal hydatid cyst: A case report. East J Med 2010; 15: 76-9.

8. Dharsandia MV, Soni ST, Vegad MM. Ovarian hydatid cyst in pediatric patient commencing as ovarian tumor: a rare site of echinococcosis.Int J Prev Med 2012; 3: 897-9. [CrossRef]

9. Kesici U, Kesici S, Türkmen ÜA, Ulusoy H, Duman A, Burakgazi G, et al. Primary cyst hydatid in the neck; report of one case. Turkiye Parazitol Derg 2011; 35: 2: 17-9. 